\title{
Influence of Neem Coated Urea and Micronutrients on Performance of Rice under Aerobic Condition
}

\author{
Gayatri Kumari* and S.K. Chaudhary \\ Department of Agronomy, Dr. Rajendra Prasad Central Agricultural University, India \\ *Corresponding author
}

\section{A B S T R A C T}

\begin{tabular}{|l|}
\hline K e y w o r d s \\
$\begin{array}{l}\text { Aerobic rice, Prilled urea, } \\
\text { Neem coated urea, Iron } \\
\text { and zinc, Yield, N, P and } \\
\text { K content }\end{array}$ \\
\hline Article Info \\
\hline $\begin{array}{l}\text { Accepted: } \\
16 \text { April } 2018 \\
\text { Available Online: } \\
\text { 10 May } 2018\end{array}$ \\
\hline
\end{tabular}

Aerobic rice is projected as sustainable rice production system for the immediate future. The present field experiment was carried out in split-plot design to study the impact of different sources and doses of nitrogen along with foliar spray of two micronutrients viz. iron and zinc at tillering and panicle emergence on growth and yield attributes of rice maintained under aerobic condition. The results showed that the growth and yield parameters showed positive response with higher dose of nitrogen. Data recorded at flowering and at harvest showed that number of tillers (374 and 264 respectively) and dry weight (379 and $900 \mathrm{gm}^{-2}$ respectively) was maximum when applied through neem coated urea@ $140 \mathrm{~kg} \mathrm{~N} / \mathrm{ha}$. However, plant height at flowering and harvest was noted highest $(115 \mathrm{~cm})$ for prilled urea@140 kg N/ha. Similarly, yield $(41.28 \mathrm{q} / \mathrm{ha})$ and $\mathrm{N}, \mathrm{P}$ and K content were also recorded maximum for neem coated urea@ $140 \mathrm{~kg}$ N/ha. For micronutrients, the maximum grain yield (39.34 q/ha) was recorded with $\mathrm{S}_{3^{-}}$Two foliar spray of iron and zinc at tillering and panicle emergence.

\section{Introduction}

Rice (Oriza sativa L.) is the major cultivated crops of India with 43.38 million hectares (M ha) area and 104.32 million tons (Mt) production. It is the single largest user of fresh water that consumes about $30 \%$ and more than $45 \%$ of fresh water in world and Asia respectively (Barker et al., 1999). It accounts for more than $40 \%$ of the food grain production, providing direct employment to $70 \%$ people in Indian rural areas. Being a staple food for more than $65 \%$ of the people, our national food security relies on the growth and stability of rice production. Traditional rice cultivation requires continuous irrigation or flooding that raises the question on the availability of water in future. Thus, it is very crucial to adopt a low water utilizing approach that can produce enough to meet the food demands of increasing population without hampering the water availability in the long run.

Aerobic rice is projected as sustainable rice production system for the immediate future to address water scarcity, soil health and environmental safety in the scenario of global warming (Basha and Basavarajappa, 2016). International Rice Research Institute developed the "aerobic rice technology" to address the water crisis in tropical countries. 
In aerobic rice system, wherein the improved rice cultivars are established in non-puddled, non-flooded fields and rice is grown like an upland crop (unsaturated condition) with adequate inputs and supplementary irrigation when rainfall is insufficient (Bouman, 2006).

Nutrient management in rice grown under aerobic condition plays an important role in determining the biomass production. In aerobic rice cultivation there are chances of reduced production not only due to the limitation of water for root extraction and transpiration but also due to difficulty in nutrient access by the roots. Due to reduced moisture in the soil, the nutrients remain unavailable near the root zone. Therefore, in such condition proper nutrient management practices along with soil moisture is required to maximize the productivity.

Nitrogen is one of the most important and essential nutrients for rice production that directly influences the growth, development, yield and quality of rice. It is universally deficient in majority of agricultural soils which often limits the rice yield and it is impossible to do successful arable farming without the use of fertilizers. The difference in soil $\mathrm{N}$ dynamics and pathways of $\mathrm{N}$ losses in dry sown rice system may result in different fertilizer $\mathrm{N}$ recoveries. With even high $\mathrm{N}$ applications in aerobic rice, grain filling may be limited by a low contribution of post anthesis assimilates (Zhang et al., 2009). Fertilizers upon addition to soil are subjected to numerous reactions, transformations and nitrogen losses mechanisms.

\section{Neem coated urea}

Urea is a major $\mathrm{N}$ fertilizer used for optimum crop yields all over the world. Addition of urea in soil by virtue of hydrolysis, increases soil $\mathrm{pH}$ thereby causing ammonia volatilization losses. Under the alternate drying and wetting, nitrogen is lost due to nitrification followed by denitrification as a result of oxidation and reduction. As a result the nitrogen use efficiency is discouragingly low. For upland rice it hardly exceeds $50 \%$ (Roy and Chandra, 1979). Modification in fertilizer management practices can lead to reduced losses of $\mathrm{N}$ and increased fertilizer NUE. Oil derived from seeds of neem (Azadirachta indica) contains meliacins (generally known as neem bitters) of which Epinimben, Deactetyl, Salaninand and Azadirachtin are the active ingredients, which show nitrification activation action (Devakumar and Goswami, 1992). It has been established that neem products when applied along with urea are capable of enhancing NUE in rice (Agarwal et al., 2013).

\section{Iron and Zinc}

Iron $(\mathrm{Fe})$ deficiency in aerobic rice mainly occurs under limited moisture condition, particularly under alkaline and calcareous soils. One or more of the following can cause Fe deficiency in rice, viz. low concentration of soluble iron, high $\mathrm{pH}$, wide $\mathrm{P} / \mathrm{Fe}$ ratio, fast oxidation of ferrous iron, immobilization in the roots and excessive concentration of other metallic cations and low potential of rice cultivars for excretion of organic acids (Mori et al., 1991) responsible for Fe solubilization. The aerobic rice system relies on the adequate supply of plant nutrients particularly iron $(\mathrm{Fe})$ which may become deficient under aerobic condition. Sometimes severe chlorosis in rice due to Fe-deficiency has led to complete failure of the crop (Violante et al., 2003). Soil moisture regimes play a major role in controlling the solubility and consequent availability of Fe.

Zinc $(\mathrm{Zn})$ is one of the essential micronutrient elements which play an important role in auxin production, preferential accumulation of chlorophyll protein synthesis and starch 
metabolism. Therefore, deficiency of zinc in soils adversely affects the growth and development of crops. In rice, $\mathrm{Zn}$ deficiency is referred to as Khaira disease wherein plants show appearance of dusty brown spots on upper leaves, stunted growth of plants, decreased tillering ability and spikelet sterility. $\mathrm{Zn}$ deficiency is a serious agricultural problem as around one-half of the cereal-growing soils in the world contain low $\mathrm{Zn}$ in the soil (Graham and Welch, 1996; Cakmak et al., 1999)

The deficiency of Fe and $\mathrm{Zn}$ frequently occurs in calcareous soil and more so in high $\mathrm{pH}$, drought prone areas, which severely restricts the initial growth and vigor and ultimately reduces the rice productivity. The critical concentration of $\mathrm{Fe}$ and $\mathrm{Zn}$ in soil is $6.95 \mathrm{ppm}$ and $<1 \mathrm{ppm}$ while for plant this concentration is $<50 \mathrm{ppm}$ and $20 \mathrm{ppm}$ respectively (Neue et al., 1998)

The application of $\mathrm{Fe}$ and $\mathrm{Zn}$ not only increases grain and straw yield of crop. There have been evidences that foliar spray of $\mathrm{Zn}$ and Fe under field condition may be highly effective and practical to maximize uptake and accumulation of $\mathrm{Fe}$ and $\mathrm{Zn}$ in rice. When compared to soil application, foliar applications of Fe and $\mathrm{Zn}$ are more effective. Soil application of $\mathrm{Fe}$ salts is ineffective in controlling Fe-deficiency except when application rates are large (Pal et al., 2008). Although in most of the studies foliar application has an edge over soil application (Rattan et al., 2008; Abadia et al., 2011) major problem with the foliar application is poor translocation of $\mathrm{Fe}$ within the plant (Chen and Barak, 1982). Similarly, although foliar application of $\mathrm{Zn}$ is a promising method to increase seed concentration, its effectiveness may also depend on several factors of which one factor is the time of application. Time of foliar micronutrient application is an important factor determining the effectiveness of the foliar applied fertilizer in increasing grain micronutrient concentration (Ozturk et al., 2006). For sustainable aerobic rice production there is a need to find out ways and means of effective $\mathrm{Fe}$ and $\mathrm{Zn}$ management.

Keeping in view of the above facts and future prospects of aerobic rice technology, the present investigation entitled, "Influence of neem coated urea and micronutrients on the performance of rice under aerobic condition" was planned to maximize yield and profitability of rice crop with following objectives:

To study the effect of neem coated urea and micronutrient on growth, yield and nutrient uptake.

To work out the economics of various treatments.

\section{Materials and Methods}

\section{Experimental site}

The present investigation was carried out during kharif season of 2016 at the Research Farm of Dr. Rajendra Prasad Central Agricultural University, Pusa (Samastipur) Bihar.

\section{Location}

Dr. Rajendra Prasad Central Agricultural University, Pusa is situated on the southern bank of the river Burhi Gandak in Samastipur district at $25^{\circ} 59^{\prime}$ North latitude and $84^{\circ} 40^{\prime}$ East longitudes with an altitude of $52.3 \mathrm{~m}$ above the mean sea level.

\section{Soil of the experimental site}

The soil was Entisols, sandy loam in texture characterized by high $\mathrm{pH}(8.4)$ and low EC $\left(0.38 \mathrm{dsm}^{-1}\right)$, organic carbon content $(0.36 \%)$, 
available N (212 kg/ha), available phosphorus (17 kg/ha), available potassium (104 kg/ha), DTPA extractable zinc $(0.72 \mathrm{mg} / \mathrm{kg})$ and iron $(6.7 \mathrm{mg} / \mathrm{kg})$.

\section{Meteorological conditions}

The meteorological data related to the weather conditions prevailing during crop season Kharif-2016 with respect to rainfall, relative humidity (at 7:00 hours and 14: 00 hours) and temperature obtained from Agrometeorological advisory services, Department of Agronomy, RAU, Pusa. The total rainfall of $853.6 \mathrm{~mm}$ was recorded during the cropping period of the year 2016. The mean maximum temperature ranged from $29.6^{\circ} \mathrm{C}$ to $35.5^{\circ} \mathrm{C}$ and the mean minimum temperature ranged from $23.0^{\circ} \mathrm{C}$ to $27.2^{\circ} \mathrm{C}$. Maximum and minimum relative humidity was in the range of $76 \%$ to $95 \%$ and $51 \%$ to $86 \%$.

\section{Design of experiment}

The experiment was conducted in split plot design which was replicated thrice taking the variety 'Abhishek' as a test crop. The main plot comprised of (A) Nitrogen sources (4 levels): $\mathrm{M}_{1}-120 \mathrm{~kg}$ N/ha prilled urea, $\mathrm{M}_{2}-120$ $\mathrm{kg}$ N/ha neem coated urea, $\mathrm{M}_{3}-140 \mathrm{~kg} \mathrm{~N} / \mathrm{ha}$ prilled urea and $\mathrm{M}_{4}-140 \mathrm{~kg} \mathrm{~N} / \mathrm{ha}$ neem coated urea and the sub plot consisted of (B) Micronutrients (4 levels): $\mathrm{S}_{0^{-}}$Control, $\mathrm{S}_{1^{-}}$ Two foliar spray of $\mathrm{FeSO}_{4}$ at tillering and panicle emergence, $S_{2^{-}}$Two foliar spray of $\mathrm{ZnSO}_{4}$ at tillering and panicle emergence and $\mathrm{S}_{3}$ - Two foliar spray of $\mathrm{FeSO}_{4}$ and $\mathrm{ZnSO}_{4}$ at tillering and panicle emergence. Neem coated urea was applied as basal at the time of land preparation before sowing of the crop. Prilled urea was applied in splits of 50\%, 25\% and $25 \%$ at basal, tillering and panicle initiation as per respective treatments. Phosphorus $(60 \mathrm{~kg}$ $\left.\mathrm{ha}^{-1}\right)$ in the form of SSP and potash $\left(40 \mathrm{~kg} \mathrm{ha}^{-}\right.$ ${ }^{1}$ ) in the form of MOP was applied in all the treatments including control. Zinc and Iron was applied in the form of zinc sulphate and iron sulphate respectively as foliar spray, the concentration of which was $0.5 \%$ and $1 \%$ respectively.

\section{Results and Discussion}

Growth parameters i.e., plant height, number of tillers and dry weight were recorded at $50 \%$ flowering and at harvest, the interpretation of which has been given in Table 1 .

\section{Plant height (cm)}

The appraisal of data pertaining to plant height at flowering and at harvest showed that there was trend of increase in plant height up to harvest regardless of the treatments. Among the $\mathrm{N}$ sources and levels, maximum plant height was recorded with the higher doses of nitrogen i.e. $140 \mathrm{~kg} \mathrm{~N} / \mathrm{ha} . \mathrm{M}_{3}-140 \mathrm{~kg} \mathrm{~N} / \mathrm{ha}$ prilled urea recorded the maximum plant height both at flowering and harvest (56 and $115 \mathrm{~cm}$ respectively), though it was statistically at par with $\mathrm{M}_{4}-140 \mathrm{~kg} \mathrm{~N} / \mathrm{ha}$ neem coated urea (55 and $105 \mathrm{~cm}$ respectively). Whereas among the micronutrient application, the maximum plant height was recorded with $\mathrm{S}_{3}$ - Two foliar sprays of $\mathrm{FeSO}_{4}$ and $\mathrm{ZnSO}_{4}$ at flowering and PE. At both the flowering and at harvest stage (56 and $110 \mathrm{~m}$ respectively).

The sources of nitrogen could not give a significant difference in respect of plant heights. The increased in the plant height with the application of prilled urea was because of its 3 split applications during the critical growing stages of rice that increased the nitrogen use efficiency and enhanced the stem elongation of rice. Similar results were shown by Rashid et al., (2016). The slow release of nitrogen from neem coated urea could not help in increasing the plant height.

Higher plant height was recorded with $\mathrm{S}_{3^{-}}$ Two foliar sprays of $\mathrm{FeSO}_{4}$ and $\mathrm{ZnSO}_{4}$ at 
flowering and PE. The complementary use of zinc and iron augmented the individual efficiency to maintain a higher plant height. This finding is in the conformity with the results of Prashad et al., (1995) and Shanmugam and Veeraputram (2000).

\section{Number of tillers $\mathbf{m}^{-2}$}

An ascending trend in number of tillers was observed up to the initial flowering stage, after which it descended gradually irrespective of the treatments. Among the $\mathrm{N}$ treatments, $\mathrm{M}_{4}-$ $140 \mathrm{~kg} \mathrm{~N} / \mathrm{ha}$ neem coated urea recorded the maximum number of tillers both at flowering and harvest (374 and 264 respectively) remaining statistically at par with $\mathrm{M}_{3}-140 \mathrm{~kg}$ N/ha prilled urea (368 and 259 respectively).

Among micronutrient applications, $\mathrm{S}_{3^{-}}$Two foliar sprays of $\mathrm{FeSO}_{4}$ and $\mathrm{ZnSO}_{4}$ at flowering and $\mathrm{PE}$ recorded maximum number of tillers both at flowering and at harvest (370 and 252 respectively).

Periodic observation of number of tillers $\mathrm{m}^{-2}$ indicated that, irrespective of the treatments, number of tillers increased up to initial flowering stage and thereafter a decline in trend was observed. This might be due to mutual competition among the tillers for light, nutrients, space, water and other factors resulting in morality of the tillers. During the entire growth stages, $\mathrm{M}_{4^{-}} 140 \mathrm{~kg}$ N/ah neem coated urea recorded maximum number of tillers. The production of tillers might be due to steady and continuous availability of nitrogen through neem coated urea during the entire crop growth season. The results are in agreement with Vyas et al., (1991) and Suresh and Piria (2008).

Increase in number of tillers due to combined application of both the micronutrients can be discussed in the light of the fact that more photosynthates were produced due to increased chlorophyll content and were made available for initiation of tiller. The study was in conformity with Agboda and Fube (1983) and Verma and Neue (1984).

\section{Dry weight $\left(\mathrm{g} \mathrm{m}^{-2}\right)$}

Increase in dry matter production with advancement of crop growth stages was observed. Maximum dry weight, at flowering, was observed with $\mathrm{M}_{4}-140 \mathrm{~kg} \mathrm{~N} / \mathrm{ha}$ neem coated urea $\left(379 \mathrm{~g} \mathrm{~m}^{-2}\right)$ which was statistically at par with $\mathrm{M}_{2}-120 \mathrm{~kg} \mathrm{~N} / \mathrm{ha}$ neem coated urea $\left(352 \mathrm{~g} \mathrm{~m}^{-2}\right)$ as well as $\mathrm{M}_{3}-140 \mathrm{~kg} \mathrm{~N} / \mathrm{ha}$ prilled urea $\left(365 \mathrm{~g} \mathrm{~m}^{-2}\right)$. At harvest, dry weight under $\mathrm{M}_{4}-140 \mathrm{~kg} \mathrm{~N} / \mathrm{ha}$ neem coated urea $\left(900 \mathrm{~g} \mathrm{~m}^{-2}\right)$ was found significantly superior over rest of the treatments while remaining statistically at par with $\mathrm{M}_{3}-140 \mathrm{~kg} \mathrm{~N} / \mathrm{ha}$ prilled urea $(881 \mathrm{~g}$ $\mathrm{m}^{-2}$ ). The micronutrient applications could not show significant effect at any of the crop growth stages. However, an increase in trend was observed at successive stages and $\mathrm{S}_{3^{-}}$ Two foliar spray of $\mathrm{FeSO}_{4}$ and $\mathrm{ZnSO}_{4}$ at tillering and $\mathrm{PE}$ recorded maximum dry matter production with respect to the other treatments at flowering and harvest (367 and $856 \mathrm{~g} \mathrm{~m}^{-2}$ respectively).

The photosynthetic activities of the plants are well reflected in their dry matter production. Dry matter production was significantly influenced by $\mathrm{N}$ sources and levels at all the growth stages. Maximum dry matter was recorded with $\mathrm{M}_{4}-140 \mathrm{~kg} \mathrm{~N} / \mathrm{ha}$ neem coated urea at all the stages. The dry matter production is the cumulative effect of all the growth characters like plant height \& number of tillers and increase in all these characters resulted in higher dry matter production. Also because of higher dose of slow releasing $\mathrm{N}$ applied through neem coated urea available for nearly entire crop growth cycle resulted in better photosynthate accumulation in plants. The result is in confirmation with Devi et al., (2012) and Manjoor et al., (2006). 
Table.1 Effect of neem coated urea and micronutrients ( $\mathrm{Fe}$ and $\mathrm{Zn}$ ) on growth parameters and yield of rice

\begin{tabular}{|c|c|c|c|c|c|c|c|}
\hline \multirow[t]{2}{*}{ Treatments } & \multicolumn{2}{|c|}{ Plant height $(\mathrm{cm})$} & \multicolumn{2}{|c|}{ No. of tillers $\left(\mathrm{m}^{-2}\right)$} & \multicolumn{2}{|c|}{ Dry weight $\left(\mathrm{gm}^{-2}\right)$} & \multirow{2}{*}{$\begin{array}{c}\text { Grain } \\
\text { yield } \\
\left(\mathbf{q} \mathbf{h a}^{-1}\right)\end{array}$} \\
\hline & $\begin{array}{l}\text { Flowe } \\
\text { ring }\end{array}$ & $\begin{array}{l}\text { At } \\
\text { harvest }\end{array}$ & $\begin{array}{l}\text { Flowe } \\
\text { ring }\end{array}$ & $\begin{array}{c}\text { At } \\
\text { harvest }\end{array}$ & $\begin{array}{l}\text { Flowe } \\
\text { ring }\end{array}$ & $\begin{array}{c}\text { At } \\
\text { harvest }\end{array}$ & \\
\hline \multicolumn{8}{|l|}{ Nitrogen forms } \\
\hline$M_{1}-120 \mathrm{~kg} \mathrm{~N} \mathrm{ha}^{-1} \mathrm{PU}$ & 55 & 111 & 316 & 207 & 318 & 757 & 35.12 \\
\hline $\mathrm{M}_{2}-120 \mathrm{~kg} \mathrm{~N} \mathrm{ha}^{-1} \mathrm{NCU}$ & 51 & 102 & 334 & 227 & 352 & 800 & 36.74 \\
\hline $\mathrm{M}_{3}-140 \mathrm{~kg} \mathrm{~N} \mathrm{ha}^{-1} \mathrm{PU}$ & 56 & 115 & 368 & 259 & 365 & 881 & 39.85 \\
\hline $\mathrm{M}_{4}-140 \mathrm{~kg} \mathrm{~N} \mathrm{ha}^{-1} \mathrm{NCU}$ & 55 & 105 & 374 & 264 & 379 & 900 & 41.28 \\
\hline SEm $( \pm)$ & 1.63 & 3.06 & 11.75 & 6.82 & 10.6 & 27.45 & 1.31 \\
\hline $\mathrm{CD}_{(\mathrm{P}=0.05)}$ & 4.79 & NS & 34.18 & 21.13 & 31.47 & 83.44 & 4.55 \\
\hline \multicolumn{8}{|l|}{ Micronutrients } \\
\hline$S_{0}-$ Control & 53 & 106 & 330 & 226 & 337 & 814 & 37.29 \\
\hline $\mathrm{S}_{1}-\mathrm{Two}$ foliar spray of $\mathrm{FeSO}_{4}$ & 53 & 107 & 332 & 237 & 349 & 838 & 38.20 \\
\hline $\mathrm{S}_{2}-\mathrm{Two}$ foliar spray of $\mathrm{ZnSO}_{4}$ & 54 & 109 & 361 & 241 & 363 & 829 & 38.16 \\
\hline $\begin{array}{l}\mathrm{S}_{3}-\mathrm{two}_{\mathrm{o}} \text { foliar spray of } \mathrm{FeSO}_{4} \& \\
\mathrm{ZnSO}_{4}\end{array}$ & 56 & 110 & 370 & 252 & 367 & 856 & 39.34 \\
\hline SEm $( \pm)$ & 1.62 & 3.04 & 11.32 & 6.97 & 10.8 & 25.94 & 1.28 \\
\hline $\mathrm{CD}_{(\mathrm{P}=0.05)}$ & NS & NS & 32.59 & 21.74 & NS & NS & 2.04 \\
\hline
\end{tabular}

Table.2 Nitrogen, phosphorus and potassium uptake in rice grain

\begin{tabular}{|c|c|c|c|}
\hline Treatments & $\begin{array}{c}\text { Nitrogen uptake } \\
\left(\mathrm{kg} \mathrm{ha}^{-1}\right)\end{array} \mid$ & $\begin{array}{l}\text { Phosphorus uptake } \\
\left(\mathrm{kg} \mathrm{ha}^{-1}\right)\end{array}$ & $\begin{array}{l}\text { Potassium uptake } \\
\left(\mathrm{kg} \mathrm{ha}^{-1}\right)\end{array}$ \\
\hline \multicolumn{4}{|l|}{ Nitrogen forms } \\
\hline$M_{1}-120 \mathrm{~kg} \mathrm{~N} \mathrm{ha}^{-1} \mathrm{PU}$ & 50.14 & 6.60 & 6.68 \\
\hline $\mathrm{M}_{2}-120 \mathrm{~kg} \mathrm{~N} \mathrm{ha}^{-1} \mathrm{NCU}$ & 53.47 & 7.17 & 8.82 \\
\hline $\mathrm{M}_{3}-140 \mathrm{~kg} \mathrm{~N} \mathrm{ha}^{-1} \mathrm{PU}$ & 59.99 & 8.27 & 8.55 \\
\hline $\mathrm{M}_{4}-140 \mathrm{~kg} \mathrm{~N} \mathrm{ha}^{-1} \mathrm{NCU}$ & 63.37 & 8.90 & 8.58 \\
\hline SEm $( \pm)$ & 1.88 & 0.25 & 0.27 \\
\hline $\mathrm{CD}_{(\mathrm{P}=0.05)}$ & 6.52 & 0.88 & 0.92 \\
\hline \multicolumn{4}{|l|}{ Micronutrients } \\
\hline$S_{0}-$ Control & 52.82 & 6.46 & 7.16 \\
\hline $\begin{array}{l}S_{1}-\text { Two foliar spray of } \\
\mathrm{FeSO}_{4}\end{array}$ & 56.73 & 7.83 & 7.61 \\
\hline $\begin{array}{l}\mathrm{S}_{2}-\mathrm{Two} \text { foliar spray of } \\
\mathrm{ZnSO}_{4}\end{array}$ & 56.29 & 7.86 & 7.72 \\
\hline $\begin{array}{l}\mathrm{S}_{3}-\mathrm{Two} \text { foliar spray of } \\
\mathrm{FeSO}_{4} \& \mathrm{ZnSO}_{4}\end{array}$ & 59.11 & 8.79 & 8.15 \\
\hline SEm $( \pm)$ & 1.34 & 0.18 & 0.18 \\
\hline $\mathrm{CD}_{(\mathrm{P}=0.05)}$ & 4.01 & 0.53 & 0.53 \\
\hline
\end{tabular}


Table.3 Cost of cultivation, gross return, net return and benefit: cost ratio of investment as affected by different treatments

\begin{tabular}{|c|c|c|c|}
\hline Treatments & $\begin{array}{l}\text { Gross return } \\
\text { (₹/ha) }\end{array}$ & $\begin{array}{l}\text { Net return } \\
\text { (₹/ha) }\end{array}$ & B: C ratio \\
\hline$M_{1}-120 \mathrm{~kg} \mathrm{~N} \mathrm{ha}^{-1} \mathrm{PU}$ & 58088 & 26848 & 0.86 \\
\hline $\mathrm{M}_{2}-120 \mathrm{~kg} \mathrm{~N} \mathrm{ha}^{-1} \mathrm{NCU}$ & 60661 & 29755 & 0.96 \\
\hline $\mathrm{M}_{3}-140 \mathrm{~kg} \mathrm{~N} \mathrm{ha}^{-1} \mathrm{PU}$ & 66075 & 34561 & 1.10 \\
\hline $\mathrm{M}_{4}-140 \mathrm{~kg} \mathrm{~N} \mathrm{ha}^{-1} \mathrm{NCU}$ & 68436 & 37242 & 1.20 \\
\hline $\operatorname{SEm}( \pm)$ & 2022 & 1080 & 0.04 \\
\hline $\mathrm{CD}_{(\mathrm{P}=0.05)}$ & 6997 & 3737 & 0.15 \\
\hline \multicolumn{4}{|l|}{ Micronutrients } \\
\hline $\mathbf{S}_{0}-$ Control & 61840 & 31943 & 1.07 \\
\hline $\mathrm{S}_{1}$ - Two foliar spray of $\mathrm{FeSO}_{4}$ & 63226 & 31127 & 0.97 \\
\hline $\mathrm{S}_{2}-\mathrm{Two}$ foliar spray of $\mathrm{ZnSO}_{4}$ & 63137 & 32603 & 1.07 \\
\hline $\begin{array}{l}\mathrm{S}_{3}-\mathrm{Two}_{\mathrm{w}} \text { foliar spray of } \mathrm{FeSO}_{4} \& \\
\mathrm{ZnSO}_{4}\end{array}$ & 65058 & 32734 & 1.01 \\
\hline SEm ( \pm ) & 1864 & 1066 & 0.03 \\
\hline $\mathrm{CD}_{(\mathrm{P}=0.05)}$ & NS & NS & NS \\
\hline
\end{tabular}

Fig.1 Grain yield (q/ha) as affected by different treatments

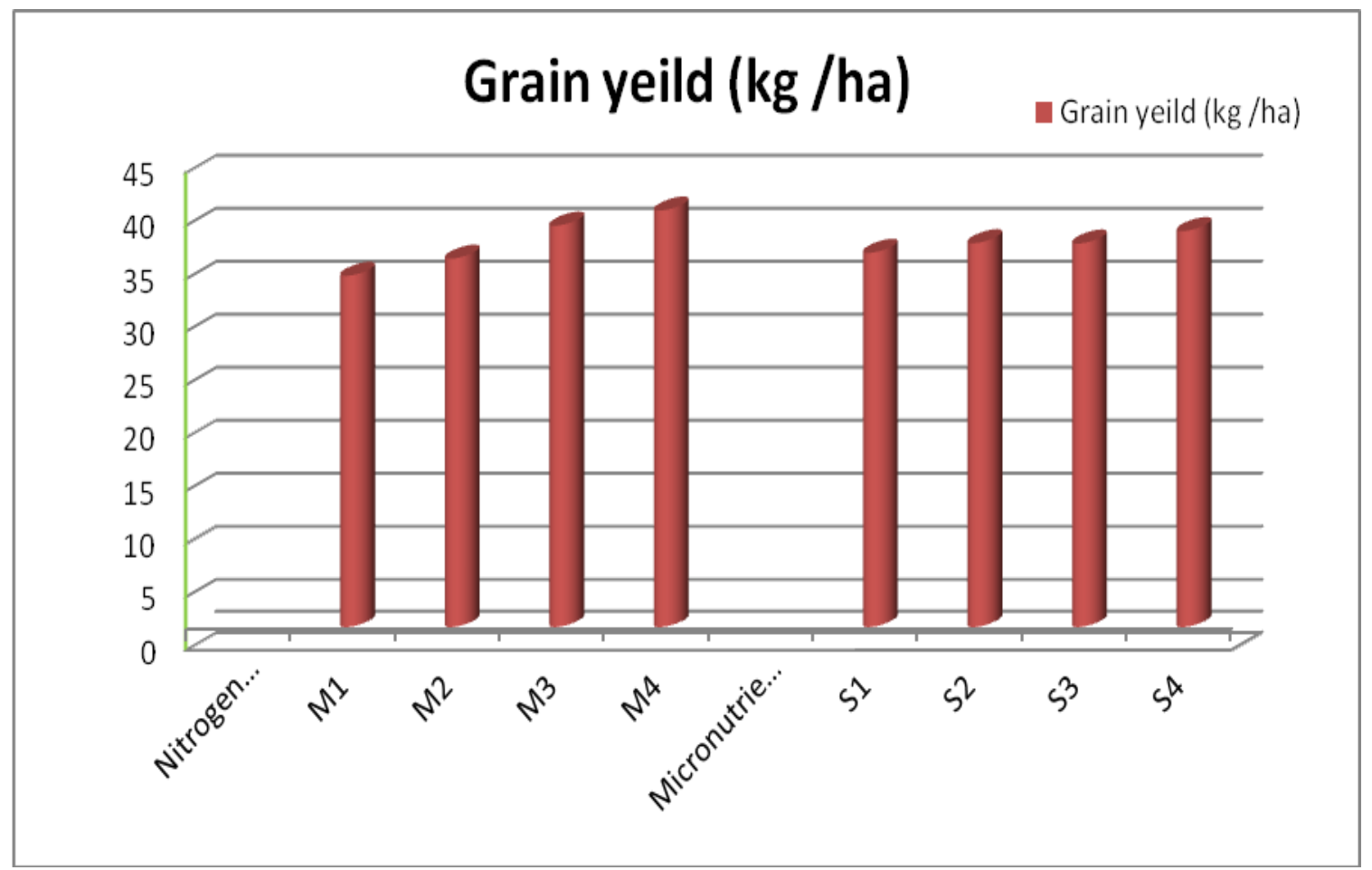


Fig.2 Gross return ( $₹$ /ha) and Net return ( $₹ /$ ha) as affected by different treatments

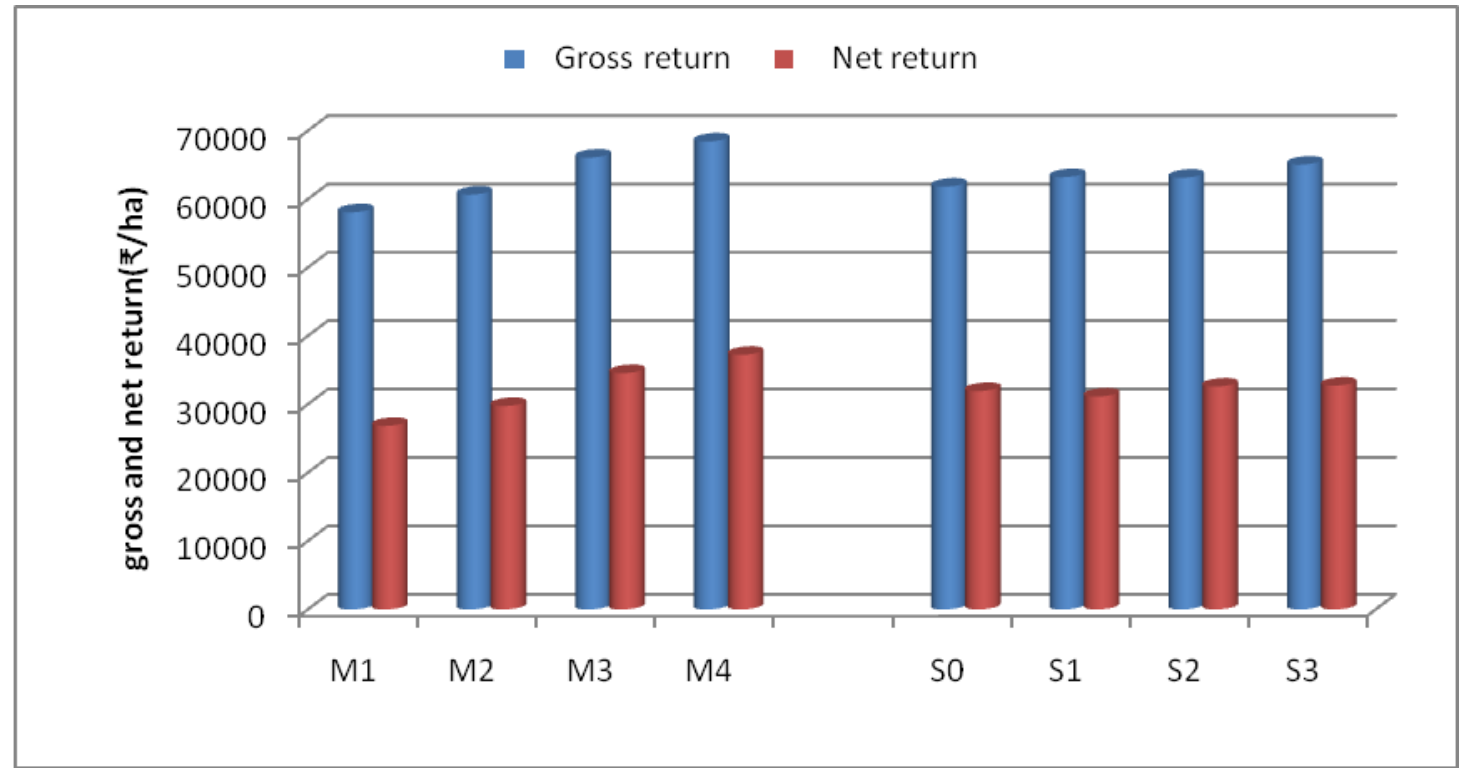

Fig.3 B: C ratio as affected by different treatments

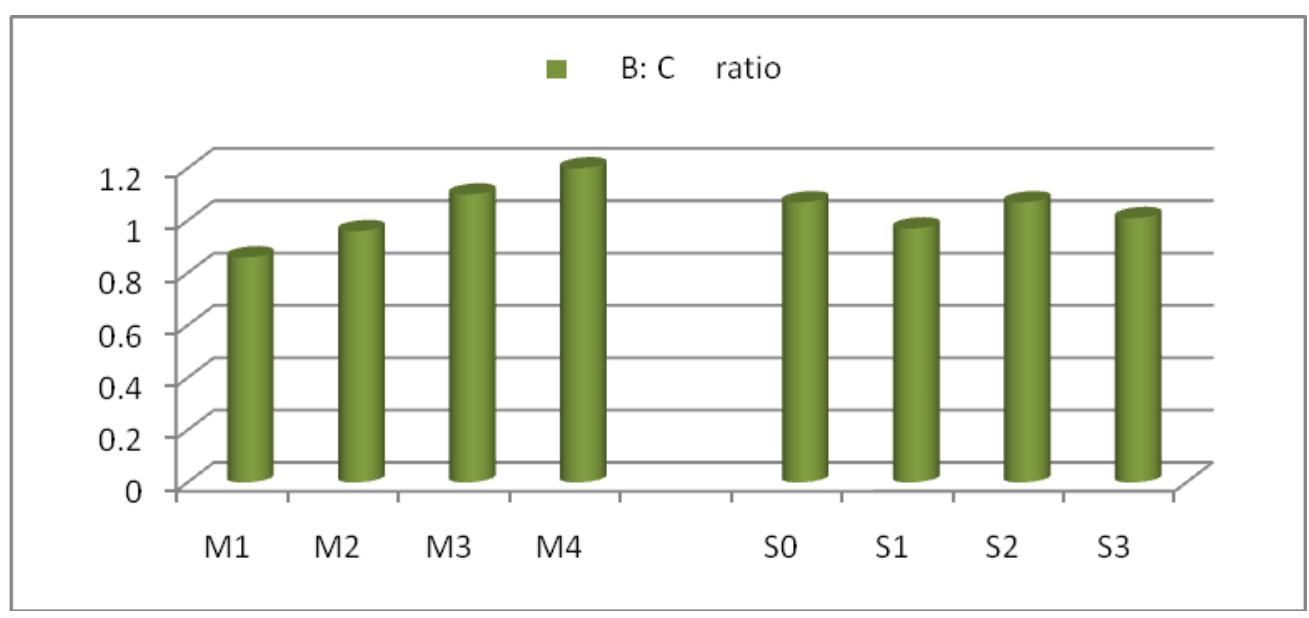

Maximum dry matter with $\mathrm{S}_{3}$ - Two foliar spray of $\mathrm{FeSO}_{4}$ and $\mathrm{ZnSO}_{4}$ at tillering and $\mathrm{PE}$ might be due to enhanced photosynthetic efficiency and synergistic effect between these nutrients. The result is in confirmation with Singh et al., (1995).

\section{Yield $\left(\mathrm{q} \mathrm{ha}^{-1}\right)$}

Perusal of data from Table 1, interprets that maximum grain yield was obtained with $\mathrm{M}_{4-}$ $140 \mathrm{~kg} \mathrm{~N} / \mathrm{ha}$ neem coated urea $\left(41.28 \mathrm{q} \mathrm{ha}^{-1}\right)$ and it was significantly superior over $\mathrm{M}_{1^{-}} 120$ $\mathrm{kg} \mathrm{N} / \mathrm{ha}$ prilled urea $\left(35.12 \mathrm{q} \mathrm{ha}^{-1}\right)$ while remaining statistically at par with $\mathrm{M}_{2}-120 \mathrm{~kg}$ $\mathrm{N} /$ ha neem coated urea $\left(36.74 \mathrm{q} \mathrm{ha}^{-1}\right)$ and $\mathrm{M}_{3^{-}}$ $140 \mathrm{~kg} \mathrm{~N} / \mathrm{ha}$ prilled urea $\left(39.85 \mathrm{q} \mathrm{ha}^{-1}\right)$.

Among the micronutrient treatments, $\mathrm{S}_{3}$ - Two foliar spray of $\mathrm{FeSO}_{4}$ and $\mathrm{ZnSO}_{4}$ at tillering and $\mathrm{PE}$ recorded maximum grain yield.

However, it remained statistically at par with rest of the treatments (39.34 q ha ${ }^{-1}$ ) (Fig. 1). 
The best performances of $\mathrm{M}_{4}-140 \mathrm{~kg} \mathrm{~N} / \mathrm{ha}$ neem coated urea and then $\mathrm{M}_{3}-140 \mathrm{~kg} \mathrm{~N} / \mathrm{ha}$ prilled urea were more or less in accordance of the growth characters i.e. plant height, number of tillers and dry weight recorded in these treatments. Increase yield due to application on neem coated urea was due to the slow release of $\mathrm{N}$ that was available throughout the life of rice, being subjected to minimum loss and helping in enhancing the reproductive phase. Second best yield was obtained with $\mathrm{M}_{3}-140 \mathrm{~kg} \mathrm{~N} / \mathrm{ha}$ prilled urea. This might be due to the higher dose of N/ha in splits, that increased the yield in comparison to the lower doses of NThe results are in parallel to Sarangi et al., (2016), Shivay et al., (2001); Jat and Pal (2002).

Increase in yields nutrients through combined foliar sprays might be due to their better absorption of and thereby their synergistic effect in the plant which increased the photosynthetic activity and effective translocation to storage organs, thus contributing to increased yield. Similar result was confirmed by Ram et al., (2011), wherein it was concluded that foliar application of $(\mathrm{Fe}$ $+\mathrm{Zn})$ at tillering and heading stage increased grain yield. Moreover their synergistic behaviour towards other elements like $\mathrm{N}, \mathrm{P}$ or $\mathrm{K}$ might also contributed to higher grain yield. The second best treatment that showed higher yields was $\mathrm{S}_{1}$ - Two foliar sprays of $\mathrm{FeSO}_{4}$ at tillering and $\mathrm{PE}$ which might be due to increased chlorophyll content in leaves, increased biochemical and physiological process in plants including $\mathrm{N}$ and $\mathrm{S}$ along with the production of plant hormone ethylene (Marschner, 1995).

\section{$\mathrm{N}, \mathrm{P}$ and $\mathrm{K}$ uptake by grain (kg/ha)}

Perusal of data (Table 2) revealed that, $\mathrm{N}$ and $\mathrm{P}$ uptake in grain was maximum with $\mathrm{M}_{4^{-}} 140$ $\mathrm{kg} \mathrm{N} / \mathrm{ha}$ neem coated urea (63.37 and 8.90 $\mathrm{kg} / \mathrm{ha}$ ) and it was significantly superior to the rest of the treatments while maintaining statistical parity with $\mathrm{M}_{3}-140 \mathrm{~kg} \mathrm{~N} /$ ha prilled urea (59.99 and $8.27 \mathrm{~kg} / \mathrm{ha}) . \mathrm{K}$ uptake in grain was also found higher in treatment $\mathrm{M}_{4}-140$ $\mathrm{kg} \mathrm{N} / \mathrm{ha}$ neem coated urea $(8.58 \mathrm{~kg} / \mathrm{ha})$, though it was statistically at par with $\mathrm{M}_{3}-140$ $\mathrm{kg} \mathrm{N} / \mathrm{ha}$ prilled urea $(8.55 \mathrm{~kg} / \mathrm{ha})$ as well as $\mathrm{M}_{2-} 120 \mathrm{~kg} \mathrm{~N} / \mathrm{ha}$ neem coated urea (8.82 $\mathrm{kg} / \mathrm{ha})$.

Among the micronutrient treatments, $\mathrm{S}_{3}$ - Two foliar spray of $\mathrm{FeSO}_{4}$ and $\mathrm{ZnSO}_{4}$ at tillering and $\mathrm{PE}$ recorded maximum $\mathrm{N}, \mathrm{P}$ and $\mathrm{K}$ uptake $59.11,8.79$ and $8.15 \mathrm{~kg} / \mathrm{ha}$ ). However, $\mathrm{N}$ and $\mathrm{K}$ uptake in grain was significantly superior to $\mathrm{S}_{0^{-}}$Control only, while $\mathrm{P}$ uptake by grain was significantly superior to the all the micronutrient treatments. Uptake of nutrients is a function of nutrient content and grain and straw yield. The pooled mean results indicated that $\mathrm{N}$ sources and levels significantly influenced the uptake of $\mathrm{N}, \mathrm{P}$ and $\mathrm{K}$ in grain. Maximum uptake was recorded with $\mathrm{M}_{4}-140 \mathrm{~kg}$ neem coated urea which might be due to cumulative effect of increase in grain yield as well as their increased content in grain. These results were supported by Nayak et al., (2015), Satpute et al., (2015), and Mallareddy and Pajmaja (2013).

The increase in $\mathrm{N}, \mathrm{P}, \mathrm{K}$ uptake with the combined application of $\mathrm{Fe}$ and $\mathrm{Zn}$ in with $\mathrm{S}_{3}$ Two foliar spray of $\mathrm{FeSO}_{4}$ and $\mathrm{ZnSO}_{4}$ at tillering and PE, might be due to better availability of nutrients and translocation within the plants as well as their enhanced transport to plant from the soil due to increased root length. Similar findings were reported by Ram et al., (2013) and Gonaa et al., (2015).

\section{Economics}

The results clearly exhibited that there was a significant variation in gross return, net return 
and $\mathrm{B}$ : $\mathrm{C}$ ratio due to various $\mathrm{N}$ management (Table 3). The maximum gross return was recorded with $\mathrm{M}_{4^{-}} 140 \mathrm{~kg} \mathrm{~N} / \mathrm{ha}$ neem coated urea (₹`68436) and it was significantly superior over the rest of the treatments. Net return and $\mathrm{B}: \mathrm{C}$ ratio was recorded maximum for $\mathrm{M}_{4-} 140 \mathrm{~kg} \mathrm{~N} / \mathrm{ha}$ neem coated urea (₹ 37242 and 1.20 respectively) which was significantly superior over rest of the treatments while remaining statistically at par with $\mathrm{M}_{3}-140 \mathrm{~kg} \mathrm{~N} /$ ha prilled urea (₹ 34561).

Among the micronutrients, maximum gross return ( $₹$ 65058) and net return ( $₹$ 32734) was found highest for $\mathrm{S}_{3}$ - Two foliar spray of $\mathrm{FeSO}_{4}$ and $\mathrm{ZnSO}_{4}$ but the increase in the amount could not reach to the level of significance. However, B: C was recorded maximum with $\mathrm{S}_{0^{-}}$Control (1.07) and $\mathrm{S}_{2^{-}}$ Two foliar spray of $\mathrm{ZnSO}_{4}$ at tillering and $\mathrm{PE}$ (1.07) (Fig. 2).

Higher economic return is an important consideration in selection of fertilizer management practices as farmers are mostly concerned with higher return per rupee investment. Economics of rice production depends on several factors such as input cost, labour requirement and above all the weather conditions prevailing during the crop period. The economics of rice production were worked out by calculation cost of cultivation item-wise and deducting it from price of different treatment cost to get net return. Gross return increased significantly with the application of various $\mathrm{N}$ sources and micronutrients. Maximum value was recorded with $\mathrm{M}_{4}-140 \mathrm{~kg} \mathrm{~N} / \mathrm{ha}$ neem coated urea in main plot and with $\mathrm{S}_{3}$ - Two foliar spray of $\mathrm{FeSO}_{4}$ and $\mathrm{ZnSO}_{4}$ in the sub-plot which were parallel to their respective increase in yield and thus their respective increase in net return. The result is in tune with Ram et al., (2013). B: C ratio was also reported maximum with $\mathrm{M}_{4}-140 \mathrm{~kg} \mathrm{~N} / \mathrm{ha}$ neem coated urea but for micronutrient treatments, maximum B: C ratio was recorded with $\mathrm{S}_{0^{-}}$ Control and $\mathrm{S}_{2-}$ Two foliar spray of $\mathrm{ZnSO}_{4}$ at tillering and PE (Fig. 3).

The experiment was conducted in split plot design to study the impact of different sources an $d$ levels of nitrogen along with the micronutrients ( $\mathrm{Fe}$ and $\mathrm{Zn}$ ) as foliar spray on the rice variety 'Abhishek' that was maintained under aerobic condition. N, P, K, $\mathrm{Fe}$ and $\mathrm{Zn}$ were applied according to their respective treatments. The other crop management practices were done as per standard package of practices. Keeping in view the limitations of present investigation that was conducted for one growing season, the following broad conclusion can be drawn:

There was significant increase in grain yield with the application of $140 \mathrm{~kg}$ N/ha neem coated urea supplemented with two foliar application of $\mathrm{Fe}$ and $\mathrm{Zn}$ at tillering and panicle emergence which can be attributed to the increased vegetative growth as could be seen by various growth parameters i.e. plant height, number of tillers m-2 and dry weight. The increase in the biomass led to the effective translocation of food and nutrients to the grain in the later stages that could help in increasing the grain yield.

The increased dose of nitrogen and foliar spray of both the micronutrients together increased the major nutrients $(\mathrm{N}, \mathrm{P}$ and $\mathrm{K}$ ) uptake which was of because the enhanced physiological functioning of the plant.

The application of neem coated urea @ 140 kg $\mathrm{N} /$ ha also registered maximum gross return, net return and B: $\mathrm{C}$ ratio as was supported by the increased grain yield.

\section{References}

Abadia, J., Vazquez, S., Rellan-Alvarez, R., ElJendoubi, H., Abadia, A., AlvarezFernandez, A. And Lopez-Millan, A.F., 
2011. Towards a knowledge-based correction of iron chlorosis. Plant physiol. Biochem., 49: 471-482.

Agboda, A.A. and Fube, H.N., 1983. Effect of iron on yield and performance of upland rice in south-west Nigeria. Fertilizer Res., 4(2): 119-126.

Basha, S.J. and Basavarajappa, R., 2016. Studies on organic and inorganic nutrient management practices for sustainable production of aerobic rice. J. Soils and Crops., 26(1): 14-20.

Bouman, B.A.M., 2006. Performance of aerobic rice varieties under irrigated conditions in North China. Field Crops Res., 97: 53-65.

Bouman, B.A.M., 2006. Performance of aerobic rice varieties under irrigated conditions in North China. Field Crops Res., 97: 53-65.

Cakmak, I., Kalayei, M., Ekiz, H., Braun, H.J. and Yilmaz, A., 1999. Zinc deficiency as an actual problem in plant and human nutrition in Turkey: a NATO science for stability project. Field Crops Res., 60: 175-188.

Chen, Y. and Barak, P., 1982. Iron nutrition of plants in calcareous soils. Adv. Agron., 35: $217-240$.

Devakumar, C. and Goswami, B.U., 1992. Nematicidal principals from neem isolated and bioassay of some malicious. Pestic Res. J., 4(2): 79-84.

Devi, M.G., Reddy, S.T., Sumathi, V., Reddy, S. and Aruna, A., 2012. Influence of level and time of $\mathrm{N}$ application on yield, nutrient uptake and post-harvest nitrogen status of soil in aerobic rice. Curr. Bot., 6(1): 98-102.

Gonaa, M.A., Radwan, F.I., Kandil, E.E. and Gharib, A.F., 2015. Effect of nitrogenous sources and zinc application method on productivity and quality of rice (Oryza sativa L.). Middle East J. Appl. Sci., 5(4): 913-919.

Graham, R.D. and Welch, R.M., 1996. Breeding for staple food crops with high micronutrient density. In worker papers on Agricultural strategies for micronutrients. ed. HD, Bouis, 1-72.
Washington, DC: International Food Policy Research Institute.

Jat, M.L. and Pal, S.S., 2002. Relative efficiency of pusa micro-emulsion-coated and prilled urea in rice (Oryza sativa) wheat ( $T$. aestivum) cropping system on Ustochrepts of Indo-Gangetic plain. Indian J. Agr. sci., 72(9): 548-550.

Mallareddy, M., and Padmaja, B., 2013. Response of rice (Oryza sativa) varieties to nitrogen under aerobic and flooded conditions. Indian J. Agron., 58(4): 500555.

Manjoor, Z., Awan, T.H., Zahid, M.A. and Faiz, F.A., 2006. Response of rice crop to different nitrogen levels. J.Anim. Plant Sci., 16: 1-2.

Marschner, H., 1995. Mineral nutrition of higher plant. Academic press, San Diego.

Mori, S., Nishizawa, N., Hayashi, H., Chino, M., Yoshimura, E. and Ishihra, J., 1991. Why are young rice plants highly susceptible to iron deficiency? Plant and Soil. 130: 143-156.

Nayak, B.R., Pramanik, K., Panigrahy, N., Dash, A.K. and Swain, S.K., 2015. Yield, Nitrogen uptake and nitrogen use efficiency indices of aerobic rice (Oryza sativa L.) under various irrigation regimes and nitrogen levels. Int. J. Bio-Resource, Environ. Agric. Sci., 1(2): 8-13.

Neue, H.U., Quijano, C., Senadhira, D., Setter, T., 1998. Stratgies for dealing with micronutrient disorders and salinity in lowland rice systems. Field Crops Res., 56: 139-55.

Ozturk, 1., Yazici, M.A., Yucel, C., Torun, A., Cekic, C., Bagei, A., Ozkan, H., Braen, H. J., Sayers, Z. and Cakmak, I. 2006. Concentration and localization of zinc during seed development and germination in wheat. Physiologica Plantarum. 128: 144-152.

Pal, S., Datta, S.P., Rattan, R.K., Singh, A.K., 2008. Diagnosis and amelioration of iron deficiency under aerobic rice. J. Plant. Nutr, 31(5):919-940.

Prashad, B., Prashad, J. and Prashad, R., 1995. Nutrient management for sustainable rice 
and wheat production in calcareous soil amended with green manuring, organic manures and zinc. Fert. News, 40: 39-45.

Ram, U.S., 2011. Effect of Zn, Fe and FYM on growth, yield and nutrient content of rice. Ph.D. thesis, Department of Agronomy, Institute of Agricultural Sciences, B.H.U. Varanasi, India.

Ram, U.S., Srivastava, V.K., Hemantaranjan, A., Sen, A., Singh, R.K., Bohra, J.S. and Shukla, U., 2013. Effect of Zn, Fe and FYM application on growth and nutrient content of rice. Institute of Agricultural Sciences, B.H.U, Varanasi. 50(4): 351357.

Rashid, A. K.M.H., Chowdhury, K., Sabagh, A. E., Barutcular, C., Islam, M. S. 2016. Effect of split application of nitrogen fertilizer on yield traits and yield of high yielding aromatic rice varieties in Bangladesh. Agricultural Advances. 5(11): 368-374.

Rattan, R.K., Datta, S.P., Chhonkar, P.K., Suribabu, K. and Singh, A.K., 2005. Long-term impact of irrigation with sewage effluents on heavy metal content in soils, crops and groundwater- A case study. Agric. Ecosyst. Environ., 109: 310322.

Roy, R.N. and Chandra, S., 1979. Increasing the efficiency of fertilizer use in India. Fertilizer Industry. pp. 17-27.

Sarangi SK, Maji B, Singh S, Srivastava AK, Singh US, Sharma DK. 2016. Nitrogen management through neem coated urea and application method further improve rice productivity in coastal flood-prone rainfed lowland, $4^{\text {th }}$ International Agronomy Congress New Delhi, 2:22-26.
Satpute, S.B., Das, T., Surge, D.T. and Maity, S.K., 2015. Nitrogen management using leaf colour chart (LCC) and nitrogen level in kharif rice. Indian J. Appl. Res., 5(2): 818-820.

Shanmugam, P.M. and Veeraputram, R., 2000. Effect of organic manure, bio fertilizers, inorganic nitrogen and zinc on growth and yield of Rabi rice (Oryza sativa L.). Madras Agric. J., 87(1/3): 90-93.

Shivay, Y.S., Prasad, R., Singh, S. and Sharma, S.N., 2001. Coating of prilled urea with neem (Azadirachta indica) for efficient nitrogen use in lowland transplanted rice (Oryza sativa). Indian J. Agron., 46: 453457.

Suresh, S. and Piria, R.S., 2008. Studies the bioefficacy of neem coated urea in rice. An Asian J. Soil Sci., 3(2): 333-335.

Verma, T.S. and Neue, H.U., 1984. Effect of soil salinity level and zinc application on growth, yield and nutrient composition of rice. Plant and Soil. 82: 3-14.

Violante, A., Barberis, E., Pigna, M. and Boero, V., 2003. Factors affecting the formation, nature and properties of iron precipitation products at the soil-root interface. J. Plant Nutr., 26: 1889-1908.

Vyas, B.N., Godrej, N.B. and Mistry, K.B., 1991. Development and evaluation of neem extract as a seed coating for urea fertilizer. Fert. News., 36(2): 19-25.

Zhang, J., Wang, M.Y., Wu, L.H., 2009. Can foliar iron-containing solutions be a potential strategy to enrich iron concentration of rice grains (Oryza sativa L.) Acta Agric. Scand., 59(5): 389-394.

\section{How to cite this article:}

Gayatri Kumari and Chaudhary, S.K. 2018. Influence of Neem Coated Urea and Micronutrients on Performance of Rice under Aerobic Condition. Int.J.Curr.Microbiol.App.Sci. 7(05): 2024-2035. doi: https://doi.org/10.20546/ijcmas.2018.705.238 